\title{
The Meaning Function of the Case Particle $\int i$ in the Tsuken Island Dialect of Japanese Considered from the Perspective of Collocative Relations ${ }^{1}$
}

\author{
SATOMi Matayoshi \\ Shigakukan University, 1904-1Uchi, Hayato-cho, Kirisima-city, Kagoshima, Japan, \\ satomi.m@shigakukan.ac.jp
}

SCN III/1 [2010], 162-171

Članek predstavlja členek $\int i$ v narečju otoka Tsuken (Okinawa, Japonska), ki ima podobno funkcijo kot predlog to v angleščini. Domnevno gre za ustreznik členkov $n i$ ali $e$ v knjižni japonščini, vendar njegov izvor ni povsem jasen. $\int i$ nima le funkcije $n i$ ali $e$, temveč tudi eno izmed funkcij made knjižne japonščine. Zdi se, da se je $\int i$ razvil v narečju otoka Tsuken.

This paper describes the case particle $f i$ in the Tsuken Island dialect of Okinawa, Japan. This particle has a similar function to the preposition to in the English language. It is thought that $\int i$ is equivalent to case particles $n i$ or $e$ in the Japanese standard language, but its origin is not clear. $\int i$ has not only the function of $n i$ or $e$, but also one of the functions of Standard Japanese made. It seems that $f i$ developed in the Tsuken Island dialect.

Ključne besede: narečje otoka Tsuken, členek, kolokativni odnosi, naštevanje

Key words: Tsuken Island dialect, case particles, collocative relations, enumeration

${ }^{1}$ I very much appreciate Dr. Wayne P. Lawrence's (The University of Auckland) assistance in translating my paper. 


\section{About Tsuken Island}

Tsuken Island lies about $5 \mathrm{~km}$ southeast of the Yokatsu peninsula which is located on the east coast side of the central part of the main island of Okinawa. The island is $8 \mathrm{~km}$ in circumference and it has an area of $1.75 \mathrm{~km}^{2}$. Geographically, Tsuken Island is located in the southern district of the main island of Okinawa. However, the Tsuken Island dialect is close to the dialects of northern Okinawa and it is now established that it belongs to the northern Okinawan dialect group.

Most of the islanders make a living from fishing and agriculture. In particular, the cultivation of carrots is popular and Tsuken Island is also called "Carrot Island". The sea is blue and clear and the beach is excellent. Visitors are increasing every year, but on the other hand the population is decreasing. The island was serviced by $10-11$ round trips per day until 3 years ago, but the service has now been reduced to 5 round trips per day. The younger generation (under forty) who have grown up on the island can understand the dialect, but cannot use it. Such a severe situation may accelerate the extinction of the dialect. The Tsuken Island dialect is a so-called "Endangered Language".

\section{The function of the Tsuken Island dialect case particle $\mathrm{fi}$}

The case particle $\int i^{2}$ interacts with the movement feature of verbs and marks nouns for direction of the destination or direction of movement. It has a semantic function similar to the English preposition to or the Standard Japanese case particle $e$. The following example sentences are taken from natural conversations. ${ }^{3}$

1) $\mathrm{Na \Phi a}=\int \mathrm{i} \quad$ nzu-tap. $\quad(\text { of } \rightarrow \mathrm{I})^{4}$

Place name $=$ ALL go out- PST

(When I was young, I was in Naha.

2) inagu tou $=$ nu $\quad \mathrm{ja}:=\int \mathrm{i} \quad$ he:ku ika-n=ro. $\quad($ of $\rightarrow \mathrm{I})$

woman person $=\mathrm{GEN}$ house $=\mathrm{ALL}$ early go- $\mathrm{NGT}=\mathrm{SFP}$

A woman doesn't go to others' houses early (on New Year's Day).

There are many other verbs in the Tsuken Island dialect, for example those meaning 'come', 'return', 'visit', which are used with the case particle $\int i$.

${ }^{2}$ Case particles which express direction and which are cognate with $f i$ are found in the dialects of northern Okinawa. They differ from dialect to dialect, being attested as [ $\mathrm{g} i]$, [katfi], [hatfi], and the like. I do not know whether the cognate particles in these other dialects are used in the same correlative relation to forms equivalent to kara as Tsuken Island dialect has.

${ }^{3}$ All Tsuken Island data in this paper has been collected by the author in the course of her investigations into the dialect of Tsuken Island from 2002 to 2009. The examples in this paper have been taken from natural conversations.

${ }^{4}$ This shows who said the utterance and to whom. The abbreviations stand for the following: of: old woman / om: old man / mf: middle-aged woman / mm: middle-aged man. 


\section{The function of the Tsuken Island dialect case particle kara (ablative)}

The case particle $k a r a^{5}$ has the semantic function of indicating the starting point of time and location. Its semantic function is similar to the English preposition from. Additionally, kara has the function of marking the instrumental and locative case, but these functions will not be described here. For the moment we shall focus on the function which indicates a starting point.

\subsection{The temporal function of the case particle kara}

First, I will give examples of the function of the case particle kara which indicates a temporal starting point as follows.

3) nama $=$ kara ikuru $(\mathrm{mf} \rightarrow$ of $)$

Now $=\mathrm{ABL} \quad$ go. $\mathrm{ADN}$

I will go now.

4) raicu: $=$ kara $\quad$ sani $\quad$ makuru $=\mathrm{mub}=\mathrm{ja}:=$ na. $\quad($ of $\rightarrow$ of $)$

next week $=\mathrm{ABL}$ seed $\quad$ sow $=\phi=\mathrm{SFP}=\mathrm{Q}$

You are going to sow the seeds from next week, aren't you?

As shown above, the time that the action and the act are begun is indicated by the case particle kara. With this function, the case particle kara can be combined with various types of verb in the Tsuken Island dialect.

\subsection{The locational function of the case particle kara}

Next, I give examples of the case particle kara which indicates a locational starting point.

5) o:jama=kara $\quad$ ci-sab $=$ jo. $\quad($ of $\rightarrow$ of $)$

Place name $=\mathrm{ABL} \quad$ come-PST $=\mathrm{SFP}$

She came from Oyama.

6) uma=kara massugu nzi-ne sansaro-gwa:=ga $a:=$ mun=na.

here $=\mathrm{ABL}$ straight go-CVB. $\mathrm{CND}$ three forked road-DIM=NOM $\mathrm{COP}=\phi=\mathrm{Q}$

(of $\rightarrow$ of $)$

There is a three-forked road when going straight ahead from here, isn't there?

${ }^{5}$ There is a similar case particle kara in the standard language, but the range of functions is not identical. Both the standard language and the Tsuken Island dialect particles have the function of the marker of beginning. However whereas kara also functions to indicate instrument and the location of movement in the Tsuken Island dialect, the standard language kara does not have these functions. 
The case particle kara functions to indicate the locational starting point of movement in the Tsuken Island dialect.

\section{The function of the Tsuken Island dialect case particle mari}

The case particle mari $^{6}$ has the semantic function of indicating the end point or limit of time and location. It has a semantic function similar to the English prepositions to and until.

\subsection{The temporal function of the case particle mari}

First, I will give examples of the function of the case particle mari which indicates a temporal end point or limit as follows.

7) jozi=mari aciri-kisu- $n=r o . \quad(o m \rightarrow o f)$

NUM=LMT play-PRF-NPST=SFP

She has played until four o'clock.

8) nizu:go=mari=ja na: naФa. (of $\rightarrow \mathrm{I})$

NUM=LMT=EMP DSC Place name

I was in Naha until 25 years old.

In the Tsuken Island dialect the case particle mari indicates the temporal end point of a continuing action or state.

\subsection{The locative-indicating function of the case particle mari}

Next, I will give examples of the function of the case particle mari which indicates a locational end point or limit as follows.

9) ja:mi je nakanomatci=mari second person DSC Place name $=$ LMT

attca-ku-m=ba. $\quad($ of $\rightarrow$ om $)$

Do you walk to Nakanomachi?

10) ukibaru-gwa: $=$ mari $\quad$ ndtu-n $=$ tou $\mathrm{b}=$ jo. $\quad($ of $\rightarrow$ of $)$

Place name-DIM $=$ LMT go-NPST $=\mathrm{HS}=\mathrm{SFP}$

I heard that he will go to Ukibaru Island.

The case particle mari functions to indicate the locational arrival point of movement. In addition, it seems that it conveys a feeling of marvel or surprise. For example, in sentence 9) there is a feeling of surprise regarding walking

${ }^{6}$ The standard language has the cognate case particle made which has virtually the same function as Tsuken Island dialect mari. 
to Nakanomachi. The speaker is surprised because the addressee had walked such a long distance.

\section{The collocation of kara and $\int i$, and kara and mari}

Collocations of kara and fi, and kara and mari $^{7}$ are used in the Tsuken Island dialect. These have a similar function to that of the prepositions from and to in English. When these collocations are considered, it is noted that the former cannot be used in a temporal sense. Let us look at some examples.

\subsection{The collocation of locational kara and $\mathrm{Ji}$}

First, I will give examples of the collocation of kara and $f i$. This expression $\mathrm{N}=$ kara $\mathrm{N}=\int i$ is used when indicating a range in space. It is not used to indicate time.

11) penna $=$ kara uma $=6 i \quad$ iku-tam $=$ ba:jo jamagusuku $=6 i=r u . \quad(o f \rightarrow o f)$ Place name $=\mathrm{ABL}$ here $=\mathrm{ALL}$ go-PST $=\mathrm{SFP} \quad$ Place name $=\mathrm{ALL}=\mathrm{EMP}$ I went from Henna to Yamagusuku.

12) pe:bara $=$ kara $\quad$ uma $=6 i \quad$ ido: $6 i-k i c i=k a r a \quad$ gozu:gokanen $=$ naru. $($ of $\rightarrow I$ ) Place name $=\mathrm{ABL}$ here $=\mathrm{ALL}$ move $-\mathrm{PRF}=$ after $\mathrm{NUM}=$ pass 55 years have passed since I moved to Tsuken Island from Haebaru.

\subsection{The collocation of temporal and locational kara and mari}

Next, I will give examples of the collocation of kara and mari. The expression $\mathrm{N}=$ kara $\mathrm{N}=$ mari is used when showing a range in either space or time. In example 13) it functions to indicate location, and in 14) it indicates time.

13) i-tcai ki-sai he:bara $=$ kara $\quad$ kiDwam $=$ mari. $\quad($ of $\rightarrow$ of $)$ go-ITER come-ITER Place name=ABL Place name $=\mathrm{ALL}$

I went back and forth from Haebaru to Kin Bay.

14) jozi $=$ kara $\quad$ gozi $=$ mari $=$ ja-gutu $=$ jo $\quad$ ju:ban $=$ nu

$\mathrm{NUM}=\mathrm{ABL} \quad \mathrm{NUM}=\mathrm{LMT}=\mathrm{COP}-\mathrm{CVB} . \mathrm{CSL}=\mathrm{IJP} \quad$ supper $=\mathrm{TOP}$

nu:kui doumbi-ci: $=$ kara. $\quad$ (of $\rightarrow$ of)

variously make-PRF=CVB.CND

Because the meeting was from 4:00 to 5:00, after I made supper, I went out.

${ }^{7}$ These collocations exist both in the Tsuken Island dialect and in Standard Japanese. The case particles kara and $f i$ are used as markers to indicate enumeration in the Tsuken Island dialect, but the collocation of kara and $n i$ or $e$ in Standard Japanese lacks this function. 
Judging from the above, we can conclude the following. The form $\mathrm{N}=k a r a$ $\mathrm{N}=\int i$ is mainly used in combination with verbs of movement. This is probably due to the influence of the case-marking particle $f i$. On the other hand, the form $\mathrm{N}=$ kara $\mathrm{N}=$ mari focuses on the range of time or location.

\section{The enumeration function of $t u, t u k a$ and $\mathrm{N}=k a r a \mathrm{~N}=\int i$}

In the Tsuken Island dialect the case particles kara and $f i$ are used as markers which indicate enumeration. To be specific, kara is the marker of beginning, and $f i$ is the marker of ending. In addition to this, the case particles $t u$ and tuka also function to indicate enumeration. I will describe the features of these particles in the following two subsections.

\subsection{The function of the particle tu}

First, let us look at examples where the case particle $t u$ is used.

15) tco:nan=tu zinan $=$ tu ru rokunan=tu ukina:. $($ of $\rightarrow$ of $)$ Eldest son=EQL second son=EQL sixth son=EQL Place name The eldest son, the second son, and the sixth son are in Okinawa

16) je $\quad$ sa: $=$ tu $\quad$ kwa:ci-gwa: $=$ tu INTJ tea $=\mathrm{EQL}$ sweets-DIM=EQL Hey, have tea and sweets.

17) kinu: $=$ nu ju: $=$ nu fish $=\mathrm{GEN}$ Фurai $=$ tu $=$ ga kati-iki=be. (of $\rightarrow$ of $)$ eat-go $=$ SFP

$\begin{array}{ll}\text { tui }=\text { nu } & \text { karaage }=\text { tu } \\ \text { chicken }=\text { GEN } & \text { deep fry=EQL } \\ \text { itcu-tan=ro. } & (\mathrm{mf} \rightarrow \mathrm{I}) \\ \text { put-PST=SFP. } & \end{array}$

tui $=$ nu put-PST $=$ SFP

box lunch $=\mathrm{DAT}=\mathrm{TOP}$ fried food $=\mathrm{EQL}=\mathrm{NOM}$

Example 15) can be interpreted as saying that, of six brothers, three live in Okinawa. In other words all the brothers who live in Okinawa are enumerated. Next, in example 16) tea and sweets are enumerated. These two things are regarded as a set. Finally, in example 17) fried chicken and fried fish are enumerated. It is thought that other side dishes might have been in the lunch box, but two dishes were picked out as representative. The case particle $t u$ has three enumeration indicating functions. One is exhaustive enumeration, another is partial enumeration, and the third is listing as a set. ${ }^{8}$

\footnotetext{
${ }^{8}$ The standard language has cognate to and toka too, with virtually the same functions as the Tsuken Island dialect forms.
} 


\subsection{The function of the particle tuka}

Next, let us look at examples which use the case particle tuka.

18) nama meron=tuka suika $=$ tuka tsuku-tu-n $=$ ro. $(\mathrm{mf} \rightarrow \mathrm{I})$ now melon=EQL watermelon=EQL grow-PROG-NPST=SFP Now I am growing melons and watermelons.

19) cima $=$ nz $=$ je: $\quad(<\mathrm{nzi}=$ ja $) \quad$ irabutca $=$ tuka

island $=\mathrm{LOC}=\mathrm{TOP} \quad$ knobsnout parrotfish $=\mathrm{EQL}$

kamasa: $=$ ga ziko tu-raru- $\mathrm{n}=\mathrm{ro} .(\mathrm{mf} \rightarrow \mathrm{I})$

barracuda $=\mathrm{NOM}$ many fish-POT-NPST=SFP

On the island, we can catch a lot of knobsnout parrotfish and barracuda.

The function of the case particle tuka resembles that of the case particle $t u$ as used in example 17). In example 18), the melon and watermelon are enumerated, but the speaker is also growing other farm produce. In example 18), the knobsnout parrotfish and barracuda are enumerated. However, other fish can be caught around Tsuken Island. The case particle tuka has the function of partial enumeration.

\subsection{The function of the collocation $\mathrm{N}=k a r a \mathrm{~N}=\int i$}

Finally, let us look at examples where the expression $\mathrm{N}=$ kara $\mathrm{N}=\int i$ is used.

20) hanako=kara

NAME $=$ EQL.BEG

taro: $=$ nu

NAME $=$ GEM

mata
and
panaci
talk

jo: $\mathrm{ko}=6 \mathrm{i}=\mathrm{jo}$

$\mathrm{NAME}=\mathrm{EQL} . \mathrm{END}=\mathrm{IJP}$

kika-n-tan $=$ tci $=$ jo. $($ om $\rightarrow$ of $)$

hear-NGT-PST $=$ HS $=$ SFP

ta...

FIL

I heard that neither Hanako nor Yoko heard Taro's story.

21) makiko:=kara

ju:ko $=6 i$

kunu $=\mathrm{ja}:=\mathrm{nzi}$

suda-ti. (of $\rightarrow$ I)

NAME=EQL.BEG NAME=EQL.END DEM=hause=LOC grow up-CVB.PST Makiko through to Yuko grew up in this house.

22) $\mathrm{saDe}:=\mathrm{kara}$

NAME $=E Q L$

unu $=$ mise $=$ nakante

DEM=shops-APPR

I went to Sanei, Union, and Seikyo. But in these shops, all the bean-jam buns were sold out.

The expression $\mathrm{N}=$ kara $\mathrm{N}=\int i$ enumerates the entire range of items in the Tsuken Island dialect. The case particle $\int i$ is closely related to movement verbs. Because of this, the form functions to show the direction of movement or the place where someone has moved to. The particles kara and $f i$ in the expression $\mathrm{N}=$ kara $\mathrm{N}=\int i$ connect one place to another, creating a continuous line. It is thought that the $f i$ in this construction is connected with $\int i$ showing arrival point. 
In Standard Japanese $\mathrm{N}=$ kara $\mathrm{N}=$ made is used as a form of enumeration that looks like $\mathrm{N}=k a r a \mathrm{~N}=\int i$, but the the usage is not identical. For example, when saying "Taro=kara Hanako=made", there must be at least one other person in addition to Taro and Hanako (contrast Tsuken Island example 20)). It is thought that it is connected with expression $\mathrm{N}=$ kara $\mathrm{N}=$ made showing a range.

The persons who have been enumerated in examples 20) and 21) are sisters. Hanako and Yoko are two sisters and these two persons are enumerated. That is to say it is an exhaustive enumeration. In the other example, Makiko and Yuko are two of five siblings. The other three persons are not enumerated. Makiko is the oldest, and Yuko is the youngest sibling, and the siblings have been enumerated in order of the age. Actually, the sisters in example 20) have not been enumerated randomly but have also been enumerated in order of age. A time-line can be imagined. In example 22), the shops which the speaker went around are mentioned. They are likely to be enumerated in the order of having been visited, though it is not possible to conclude this for certain. It is thought that "beginning" and "ending" are indicated in this expression $\mathrm{N}=k a r a \mathrm{~N}=\int i$.

\section{Conclusion}

The characteristics of the case particle $\int i$ or the expression $\mathrm{N}=k a r a \mathrm{~N}=\int i$ of the Tsuken Island dialect can be described as follows.

The case particle $\int i$ interacts with the movement feature of verbs and assigns to nouns the function of indicating the direction of the destination of movement.

There is a collocation of kara and $\int i$. The expression $\mathrm{N}=k a r a \mathrm{~N}=\int i$ is strongly connected with verbs of movement. Because of that, the form functions to show the direction of movement or the place where someone has moved to. The expression $\mathrm{N}=k a r a \mathrm{~N}=\int i$ cannot indicate time. The case particle $\int i$ has the function of indicating direction or arrival point, but does not indicate limit. On the other hand, there is also a collocation of kara and mari, and the expression $\mathrm{N}=$ kara $\mathrm{N}=$ mari can indicate location or time. mari functions to indicate an arrival point or limit.

The case particles $t u$ and $t u k a$, and the expression $\mathrm{N}=k a r a \mathrm{~N}=\int i$, function as indicators of enumeration. When looking at the function of $t u$ in detail, we see it has three functions. One is exhaustive enumeration, another is partial enumeration, and the third is enumeration as a set. tuka has the function of partial enumeration. $\mathrm{N}=$ kara $\mathrm{N}=\int i$ invokes the image of a line, and does not enumerate at random but according to a certain order.

\section{ABBREVIATIONS}

ABL - ablative; ALL - allative; ADN - adnominal; APPR - approximative; COP - copula; CVB.CND - converb condition; CVB.CSL - converb causal; 
CVB.PST - converb past; DAT - dative; DEM - demonstrative;

DIM - diminutive; DSC - discourse marker; EMP - emphatic; EQL - equalis;

EQL.BEG - equalis (beginning marker); EQL.END - equalis (ending marker);

FIL - filler; GEN - genitive; HBT - habitual; HS - hearsay; IJP - interjectional particle;

INTJ - interjection; ITER - iterative; LMT - limitative; LOC - locative;

$\mathrm{N}$ - noun; NGT - negation, negative; NOM - nominative; NPST - non-past;

NUM - numeral; POT - potential; PRF - perfect; PROG - progressive;

PST - past; Q - question particle/marker; SFP - sentence final particle;

TOP - topic; V - verb; $\phi$ - null substantive

\section{WORKS CONSULTED}

Charles John FILLMORE, 1975: Kaku-bunpo no genri [Toward a modern theory of case and other articles]. Tokyo: Sanseido [Japanese translation by Tanaka Harumi and Funakoshi Michio].

Kenji ISHIGAKI, 1955: Joshi no rekishiteki-kenkyu [Historical study of particles]. Tokyo: Iwanami-shoten.

Takuro MORIYAMA, Yoshio NITTA and Hiroshi KUDO, 2000: Nihongo no bunpo 3 Modality [Series Japanese grammar 3: Modality]. Tokyo: Iwanami-shoten.

Yoshio NITTA, 1980: Goironteki-togoron [Lexicological syntax]. Tokyo: Meijishoin.

Mitsuyoshi NOHARA, 1986: Ryukyu-hogen-joshi no kenkyu [Research on Ryukyuan dialect particles]. Tokyo: Musashino-shoin.

- -, 1998. Shinpen Ryukyu-hogen-joshi no kenkyu [New edition: Research on Ryukyuan dialect particles]. Tokyo: Okinawagaku-kenkyujo.

Tasaku TSUNODA, 1991: Sekai no gengo to nihongo [Languages of the world and Japanese]. Tokyo: Kuroshio-shuppan.

Chokujin UCHIMA, 1984: Ryukyu-hogen-bunpo no kenkyu [Research on Ryukyuan dialect grammar]. Tokyo: Kasama-shoin.

\section{POMENSKA FUNKCIJA ČLENKA $\int i$ V JAPONSKEM NAREČJU OTOKA TSUKEN V LUČI KOLOKATIVNIH ODNOSOV}

$\mathrm{V}$ članku je predstavljen členek za označitev sklona $\int i$, ki ima podobno funkcijo kot predlog to $\mathrm{v}$ angleščini. Zasledimo ga $\mathrm{v}$ japonskem narečju otoka Tsuken (Okinawa). V članku so predstavljene naslednje štiri točke: (1) $\int i$ je povezan z lastnostjo gibanja pri glagolih, samostalnikom pa pripisuje funkcijo smeri gibanja; (2) obstaja korelacija med kara in $f i$, ki je podobna korelaciji med angleškima predlogoma from in to; (3) kara in $f i$ se uporabljata kot označevalca naštevanja: kara je označevalec začetka in $f i$ je označevalec konca; v knjižni japonščini se kot označevalec konca uporablja made; 
(4) $\int i$ ima tudi pomen made; v japonskem knjižnem jeziku se made 'dokler' uporablja kot označevalec konca časa, toda $\int i$ nima te funkcije, temveč samostalnikom pripisuje funkcijo točke prihoda. Domnevno je $\int i$ ustreznik sklonskemu členku $n i$ ali $e$ v knjižni japonščini, vendar njegov izvor ni povsem jasen. $\int i$ nima le funkcije $n i$ ali $e$, temveč tudi funkcijo made. Zdi se, da se je $\int i$ razvil v narečju otoka Tsuken. 